\title{
PENGARUH KONSENTRASI SARI KACANG HIJAU DAN TEKNIK INOKULASI TERHADAP PERTUMBUHAN MISELIA DAN HASIL JAMUR KUPING (Auricularia auricular Judae)
}

\author{
Lisa Miranda Utami ${ }^{1}$, Rosnina $\mathrm{AG}^{1}{ }^{*}$ \\ *Email: rosnina@unimal.ac.id
}

\begin{abstract}
ABSTRAK
Budidaya jamur kuping (Black jeli/Auricularia auricular Judae) menghadapi hambatan karena terbatasnya pemunculan dan komposisi media dalam budidaya jellymushroom hitam yang baik dan memenuhi persyaratan yang berkembang. Penelitian ini bertujuan untuk meningkatkan tingkat pertumbuhan miselia dan hasil dari kaldu kacang hijau dan teknik inokulasi jamur jelly hijau. Penelitian ini dilakukan di Desa Jalan Pulo Rungkom, Kecamatan Dewantara, Kabupaten Aceh Utara, dari bulan Februari sampai Mei 2018. Rancangan Acak Lengkap (RAL) dari 2 faktor dengan 3 ulangan digunakan. Faktor pertama adalah penggunaan kaldu kacang hijau (K) yang terdiri dari K0 (tanpa kaldu kacang hijau) K1 (25 ml kaldu kacang hijau) K2 (50 ml kaldu kacang hijau) K3 (75 ml kacang hijau kaldu). Faktor kedua adalah teknik inokulasi (I) yang terdiri dari I1 (tanpa meninju) I2 (meninju). Hasil penelitian menunjukkan bahwa pemberian kaldu kacang hijau dan teknik inokulasi memiliki pengaruh yang sangat signifikan terhadap kecepatan pertumbuhan miselia tetapi tidak secara signifikan mempengaruhi waktu ketika pin kepala muncul, bobot segar dari tubuh buah dari panen 1 dan 2, diameter tubuh buah dari panen pertama dan kedua. Ada interaksi antara perlakuan kaldu kacang hijau dan teknik inokulasi pada kecepatan tumbuh miselium memenuhi baglog.
\end{abstract}

Kata kunci: black jelly mushroom, kacang hijau, teknik inokulasi

\begin{abstract}
The cultivation of black jelly mushroom/Auriculariaauricular Judae faces obstacles due to the limited spawns and composition of media in the black jellymushroom cultivation that are good and meet growing requirements. The study aimed to improve the growth rates of mycelia and yield of black jelly mushroom mung bean broth and inoculation techniques. This research was carried out at Jalan Pulo Rungkom Village, Dewantara Sub-district, North Aceh Regency, from February to May 2018. Completely Randomized Design (CRD) of 2 factors with 3 replications were used. The first factor is the use of mung bean broth (K) consisting of $\mathrm{K}_{0}$ (without green bean broth) $\mathrm{K}_{1}(25 \mathrm{ml}$ of mung bean broth) $\mathrm{K}_{2}$ (50 $\mathrm{ml}$ of mung bean broth) $\mathrm{K}_{3}(75 \mathrm{ml}$ mung bean broth). The second factor is inoculation technique (I) which consisted of $I_{1}$ (without punching) $I_{2}$ (punching). The results showed that the giving of mung bean broth and inoculation techniques had a very significant effect on the growth speed of mycelia but did not significantly affect the time when pin head appeared, the fresh weight of the fruit bodies of the 1st and 2nd harvest, the fruit body diameter of the the 1st and 2 nd harvest. There was an interaction between treatment of green bean broth and inoculation techniques on the growing speed of mycelia fulfilling baglog.
\end{abstract}

Keywords: black jelly mushroom, mung bean broth, inoculation technique

${ }^{1}$ Program Studi Agroekoteknologi, Fakultas Pertanian, Universitas Malikussaleh 


\section{Pendahuluan}

Jamur kuping (Auricularia sp.) merupakan salah satu jamur kayu yang dapat dikonsumsi dan cukup dikenal di Indonesia. Jamur kuping mengandung mineral lebih tinggi dari pada daging sapi, daging kambing, dan sayur-sayuran lain. Selain itu, jamur kuping tidak mengandung kolesterol. Khasiat jamur kuping bagi kesehatan bagi manusiaantaranya, dapat mencegah penyakit darah tinggi, menurunkan kolesterol darah, menambah vitalitas, dan daya tahan tubuh, serta mengandung senyawa lentinon dan retiran yang berguna untuk mencegah tumor atau kanker (Chang \& Buswell 1990). Kandungan nutrisi untuk tiap 100 gram berat kering jamur kuping mengandung total karbohidrat $66,1 \mathrm{~g}$, protein $12,5 \mathrm{~g}$, lemak $1,7 \mathrm{~g}$, asam uronik $38,8 \%$, pektin $7,4 \%$, selulosa $4,3 \%$, dan mengandung makro elemen dan mikro elemen lainnya (Kadnikova et al., 2015).

Ditinjau dari khasiat dan nutrisi jamur kuping serta peluang pasar yang masih terbuka, jamur ini memiliki potensi yang prospektiv untuk dikembangkan. Pengembangan komoditas jamur kupingbelum sebanding dengan potensi sumber daya manusia dan sumber daya alam. Untuk itu, pengembangan jamur kuping perlu digarap dan ditingkatkan dengan pengelolaan secara intensif (Djarijah \&Siregar, 2001).

Sebagai upaya peningkatan hasil dapat diterapkan dengan memperkaya nutrisi media yang dapat menjamin pertumbuhan dan hasil jamur kuping. Pemberian sari kacang hijau dapat menambah ketersediaan nutrisi bagi jamur kuping. Kacang hijau mengandung karbohidrat sekitar 58\%, sedangkan pati kacang hijau terdiri dari amilosa $28,8 \%$ dan amilopektin $71,2 \%$. Sumiati (2009) melaporkan bahwa penambahan suplemen kacang hijau, air kelapa dan ekstrak tauge pada media baglogdapat mempercepat pertumbuhan miselia jamur kuping. Selain itu pada budidaya jamur menggunakan media baglog dapat diterapkan teknik inokulasi yang dapat mempercepat penyebaran pertumbuhan miselia yang akan berpengaruh terhadap pertumbuhan dan hasil jamur kuping. Terdapat 2 teknik inokulasi dalam budidaya jamur dengan menggunakan sistem bag log yaitu teknik pelubangan dan tanpa pelubangan. Inokulasi dengan teknik pelubangan pada bagian tengah baglog dengan kedalaman 3/4 dari tinggi baglog. Seperti yang dikemukakan oleh Risyanto (2014) bahwa teknik pelubangan pada media akan berpengaruh pada pertumbuhan dan kecepatan tumbuh miselia untuk memenuhi seluruh bagian media baglog.

Berdasarkan permasalahan diatas maka peneliti akan melakukan kajian tentang "Pengaruh pemberian kaldu kacang hijau dan teknik inokulasi terhadap pertumbuhan miselia dan hasil jamur kuping Auricularia auricular judae"

\section{Bahan Dan Metode}

Penelitian ini dilaksanakan di jalan KKA Km 1.2 Desa pulo rungkom Kecamatan Dewantara Kabupaten Aceh Utara. Penelitian ini dilakukan dari bulan Febuari sampai Mei 2018.

Alat dan bahan Alat yang digunakan dalam penelitian ini sekop, handspayer, lilin,plastik, polypropilen, karet, spatula, cincin pipa paralon, gelas ukur, sorongan, jangka sorong, karet, kertas koran, autoclav, rotan dan alat tulis. Bahan yang digunakan benih jamur mkuping, sari kacang hijau, dedak, kapur, alkohol dan air.

Penelitian ini menggunakan Rancangan Acak Lengkap (RAL) 2 faktor dengan 3 ulangan. Faktor pertama adalah 
pemberian sari kacang hijau $(\mathrm{K})$ terdiri atas: tanpa sari kacang hijau $\left(\mathrm{K}_{0}\right)$, pemberian sari kacang hijau $25 \mathrm{ml}\left(\mathrm{K}_{1}\right)$, pemberian sari kacang hijau $50 \mathrm{ml}\left(\mathrm{K}_{2}\right)$, pemberian sari kacang hijau $75 \mathrm{ml}\left(\mathrm{K}_{3}\right)$. Faktor kedua adalah teknik inokulasi (I) yang terdiri dari: tanpa perlubangan $\left(\mathrm{I}_{1}\right)$, menggunakan perlubangan $\left(\mathrm{I}_{2}\right)$. Dengan demikian diperoleh 9 kombinasi perlakuan dan setiap kombinasi diulang sebanyak 3 kali.

\section{Pelaksanaan Penelitian}

\section{Pembuatan Media Tanam}

Proses budidaya jamur kuping dimulai dari bahan baku yang terdiri dari serbuk gergaji, dedak dan kapur. Pembuatan media dicampur terlebih dahulu, adapun komposisi media yang digunakan adalah serbuk gergaji $72 \mathrm{~kg}$, dedak 7,2 kg dan kapur 2,2 kg. Setelah itu campuran bahan media diaduk merata dan ditambahkan air bersih. Kemudian dilakukan pengomposan, pengomposan dilakukan dengan membumbun media tanam yang sudah tercampur rata dan setelah itu ditutup rapat dengan terpal plastik, pengomposan dilakukan selama 3 hari.

\section{Pembuatan Media Baglog}

Setelahpengomposanselanjutnya dilakukan pengisian media ke dalam plastik polypropilene dengan kapasitas $1000 \mathrm{~g}$, pengisian media dipadatkan dengan menekanmedia agar media menjadi padat. Kemudian baglog media tanam pada bagian ujung plastik yang terbuka dipasang potongan cincin pipa paralon, dan setelah itu ditutup dengan plastik dan diikat dengan karet hingga rapat.

\section{Pemberian Sari Kacang Hijau}

Kacang hijau terlebih dahulu direndam selama 24 jam, kemudian direbus sampai mendidih, dan setelah perebusan selesai sari kacang hijau dimasukkan ke dalam wadah. Kemudian media dibuat dengan 4 bagian dan setiap bagian diberikan kaldu kacang hijau. Sari kacang hijau diaplikasikan dengan cara menuangkan sari kacang hijau kedalam media baglog, sesuai dengan perlakuan masing-masing.

\section{Sterilisasi}

Sterilisasi dilakukan dengan menggunakan autoclav, sterilisasi dilakukan selama 6 jam. Setelah itu media yang sudah disterilisasi didinginkan dan selanjutnya baru dilakukan inokulasi.

\section{Inokulasi}

Inokulasi dilakukan dengan 2 cara yaitu, tanpa perlubangan dan menggunakan perlubangan. Inokulasi tanpa perlubangan dilakukan dengan memasukkan benih pada bagian atas media. Sedangkan inokulasi dengan menggunakan perlubangan dilakukan dengan cara membuat lubang pada bagian tengah media baglogdengan menggunakan rotan, pada kedalaman 15 $\mathrm{cm}$ dengan panjang baglog $30 \mathrm{~cm}$, kemudian benih dimasukkan kedalam lubang tanam sebanyak $5 \mathrm{~g}$.

\section{Inkubasi}

Inkubasi merupakan tahap penyimpanan baglog yang sudah diinokulasi kedalam ruang inkubasi pada kondisi ruang, tempat inkubasi harus bersih agar miselia jamur tetap dapat tumbuh dengan baik.

\section{Pemeliharaan}

Suhu ruang diusahakan mencapai $28-33^{\circ} \mathrm{C}$, sedangkan kelembaban udara $80-90 \%$. Apabila suhu ruangan dan kelembaban tidak sesuai maka perlu dilakukan penyiraman dan diberi udara dengan cara membuka jendela kumbung sesuai dengan kebutuhan.

\section{Panen}

Jamur kuping siap dipanen bila ukurannya sudah mencapai pertumbuhan 
optimal yaitu, ditandai dengan ciri-ciri jamur kuping sudah mulai melebar dan mengerut keriting dengan bagian pinggir tudung sudah mulai menipis.

\section{Kecepatan Tumbuh Miselia}

Berdasarkan permasalahan diatas maka peneliti akan melakukan kajian tentang "Pengaruh pemberian kaldu kacang hijau dan teknik inokulasi terhadap pertumbuhan miselia dan hasil jamur kuping Auricularia auricular judae"

Parameter yang diamati adalah, Kecepatan pertumbuhan miselia memenuhi baglog, pemunculan tubuh buah (pin head), berat segar total tubuh buah $(\mathrm{g})$, diameter tubuh buah $(\mathrm{mm})$.

\section{Hasil Dan Pembahasan}

Hasil analisis ragam terhadap parameter yang diamati memperlihatkan bahwa konsentrasi sari kacang hijau dan teknik inokulasi.

Rekapitulasi hasil analisis ragam yang diamati dapat dilihat pada Tabel 4 .

\begin{tabular}{lcccc}
\multicolumn{1}{c}{ Pengamatan } & (K) & (I) & K x I & (\%) \\
$\begin{array}{l}\text { Kecepatan } \\
\text { Pertumbuhan }\end{array}$ & ${ }^{* *}$ & ${ }^{* *}$ & ${ }^{* *}$ & \\
$\begin{array}{l}\text { Miselia Memenuhi } \\
\text { Baglog }\end{array}$ & 269.09 & 797.01 & 61.28 & 1.95 \\
$\begin{array}{l}\text { Saat Muncul (pin } \\
\text { head) }\end{array}$ & tn & & & \\
tn 1.40 & tn 1.96 & 16.64
\end{tabular}

Berat Segar Total Tubuh Buah

$\begin{array}{ccccc}\text { Panen I } & \begin{array}{c}\text { tn } \\ \text { Panen II }\end{array} & { }^{*} 4.69 & { }^{\text {tn } 0} .96 & 11.92 \\ \text { tn } & 0.97 & { }^{*} 16.86 & { }^{\text {tn }} 0.19 & 8.15\end{array}$

Diameter Tubuh Buah

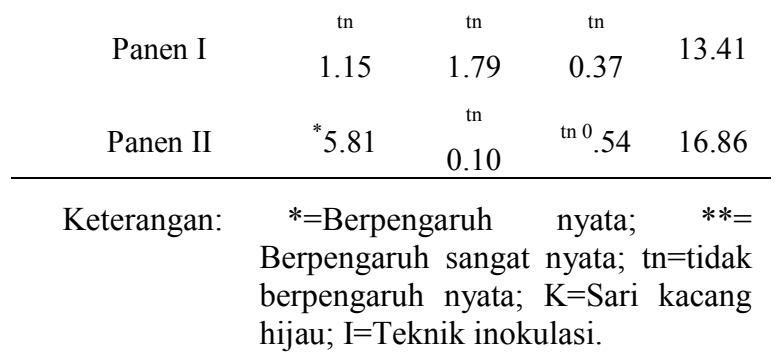

Pada Tabel 4. Terlihat bahwa dari hasil pengamatan aplikasisari kacang hijau tidak berpengaruh nyata terhadap munculnya pin head, berat segar total dan diameter tubuh buah jamur panen ke1. Tetapi berpengaruh nyata terhadap kecepatan tumbuh memenuhi seluruh bagian media baglog dan diameter tubuh buah jamur panen ke 2 .

Perlakuan faktor tunggal teknik inokulasi tidak berpengaruh nyata terhadap munculnya pin head, diameter tubuh buah jamur panen ke 1 dan ke 2, akan tetapi berpengaruh sangat nyata terhadap kecepatan tumbuhmiselia memenuhi media baglog. Padaperlakuan $\mathrm{K}_{3} \mathrm{I}_{2}$ merupakan waktu yang lebih cepat dibandingkan dengan kecepatan tumbuh miselia pada perlakuan lainnya.

Rata-rata kecepatan tumbuh miseliadengan teknik inokulasi pelubangan lebih cepat dibandingkan dengan teknik tanpa pelubangan media baglog. Kecepatan pertumbuhan miselia jamur ini selain dengan teknik inokulasi juga dapat diperoleh dengan penggunaan benih unggul yang memiliki karakteristik yang baik. Hal ini didukung oleh Rosnina et al., (2017) yang menggunakan benih hasil persilangan jamur tiram kelabu (P. Pulmonarius) dan jamur tiram kuning (P. Citrinopileatus) memiliki kecepatan tumbuh miselia jika dibandingkan dengan kedua tetuanya. Terdapat perbedaan yang signifikan dalam tingkat pertumbuhan miselium antara benih hibrida dan tetuanya. Kecepatan tumbuh tertinggi yaitu strain P19xC5 (4,0 mm/hari) diikuti oleh strain $\mathrm{P} 13 \mathrm{xC} 7$ yaitu $(3,6 \mathrm{~mm} /$ hari $), \mathrm{P} 13 \mathrm{xC} 5$ (3,3 $\mathrm{mm} /$ hari), $\mathrm{P} 9 \mathrm{xC} 7(3,2 \mathrm{~mm} / \mathrm{hari})$ dan $\mathrm{P} 19 \mathrm{xC} 2$ yaitu $(3,0 \mathrm{~mm} / \mathrm{hari})$.

Pemberian sari kacang hijau dapat meningkatkan nutrisi yang terjkandung dalam media, hal ini akan berpengaruh terhadap berat segar jamur kuping yang akan dipanen. Seperti yang dikemukakan oleh Shifriyahet al., (2012) bahwa 
pemberian nutrisi pada tingkat yang tersedia akan menjamin pertumbuhan jamur secara optimal.

Peningkatan konsentrasi kaldu kacang hijau dalam komposisi media dapat meningkatkan hasil jamur kuping. Seperti yang dikemukakan oleh

Budianto (2004) bahwa berat segar jamur yang dihasilkan ditentukan oleh kesuburan media tanam dan adanya zatzat makanan seperti karbohidrat dan protein.

\section{Kesimpulan Dan Saran}

\section{Kesimpulan}

Berdasarkan hasil penelitian dapat disimpulkan bahwa terdapat interaksi antara konsentrasisari kacang hijau dan teknik inokulasi terhadap kecepatan tumbuh miselia memenuhi media baglog.

\section{Saran}

Disarankan untuk melakukan penelitian lebih lanjut terhadap konsentrasi sari kacang hijau dengan konsentrasi lebih dari $75 \mathrm{ml}$. Sehingga memberikan pengaruh terhadap hasil jamur kuping. Penggunaan benih unggul akan dapat meningkatkan keepatan tumbuh dan hasil jamur kuping.

\section{Daftar Pustaka}

Budianto. 2004. Pengaruh Macam Media dan Dosis Bekatul Terhadap Pertumbuhan Jamur Tiram Putih (Pleurotus ostreatus). [Skripsi] Surakarta: Fakultas Pertanian Universitas Sebelas Maret, hal. 8-43.

Chang, ST \& Buswell, JA 1990, 'Mushroom nutriceutical', Worl Journal of Microbial and Biotech, vol. 121, no. 5, pp. 473-6.

Djarijah, \& A. Siregar.2001. Budidaya Jamur Kuping Pembibitan dan
Pemeliharaan.Kanisius:

Yogyakarta.

Kadnikova I. A., Costa R., Kalenik T. K., 1, Guruleva O. N., Shi Yanguo. (2015). Chemical Composition and Nutritional Value of the Mushroom Auricularia auricula-judae. Journal of Food and Nutrition Research. Vol. 3, No. 8, 478- 482.

Risyanto, S. 2014. Teknik Inokulasi Pada Budidaya Jamur Tiram. Makalah. Fakultas Biologi. Universitas Jendral Sudirman. Purwokerto.

Rosnina, A.G., Lau, N. Abdullah \&S. Vikineswary, 2017. Karakterisasi morfologi dan molekuler Pleurotus pulmonarius hibrida dengan fitur sporofor yang lebih baik dan khasiat biologis yang lebih tinggi. Institut Ilmu Biologi, Fakultas Sains, Universitas Malaya. Agric. Biol., 19: 707-712

Shifriyah, A, K. Badami dan S. Suryawati. 2012. Pertumbuhan dan produksi jamur tiram putih (Pleurotus ostreatus) pada penambahan dua sumber nutrisi. Jurnal Agrovigor, 5(1): 1-13 hal.

Sumiati, E. 2009, 'Masalah budidaya jamur edibel di pulau Jawa dan Bali', J. Agrikultura, vol. 21, no. 2, hlm.122-9. 